UDK 632.4:635.65

(C) 2016

M. Kyryk, Academician of the NAAS, Doctor of Biological Sciences

Yu. Taranukho, Candidate of Biological Sciences, National University of Bioresources and Natural Resources of Ukraine

\title{
PATOGENICITY OF ORIGINATORS OF FUSARIAL WILT OF ROOT ROT ON PEASE (PISUM SATIVUM L.)
}

The purpose. To determine pathogenic properties of fungi of genus Fusarium Link. spread on plants of pease. Methods. Laboratory (secretion in clean culture of originators of root rot of pease, growing and accumulation of contagious stuff; growing of plants of pease in conditions of artificially infected soil), mathematicalstatistical. Results. In conditions of artificially infected background pathogenic properties are studied of fungi of genus Fusarium on pease. Influence is determined of kinds of Fusarium upon germination of seeds, seeding emergence, fungal attack, further growth of plants. Conclusions. The greatest injuriousness to pease manifested $F$. Avenaceum and $F$. javanicum, the least $-F$. oxysporum.

Key words: patogenicity, Fusarium, pease, root rot, artificially infected background.

Fungi of the genus Fusarium are widely distributed in nature, most of them are known as pathogens causing diseases to the aerial parts and root of agricultural crops $[1,4,8,9,10,11]$. In the southern parts of the non-chernozem zone of one of the most harmful diseases in vegetable peas are Fusarium root rot; yield losses in its intensive development are 30 - 50\% or more [2]. In Ukraine it for this crop has not been studied.

Objective - determining the pathogenic properties of the fungi of the genus Fusarium Link., are widespread in green pea.

Materials and methods. Isolation root rots pathogens were done on rotted root samples under conditions of in vitro in problem research laboratory "Mycology and Phytopathology" of department of Phytopathology academician V. Peresypkin National University of Life and Environmental Sciences of Ukraine (NULES Ukraine) during 2012-2013 years. Identification of fungal species was 
performed 2 weeks after culturing them in nutrient medium, using the methodical recommendations given in the works of V.I. Bilai [1] V.V. Kotova and other [5], M.Y. Stepanova and other [6].To create artificial infectious backgrounds of pea root rot in soil brought pure cultures of pathogens that previously were propagated for 15 days under sterile conditions in steamed barley. The resulting inoculum was mixed with sterilized soil in the ratio of $1: 3$ and brought in the line during planting seeds at the rate of $5 \mathrm{~g} / \mathrm{m}^{2}$ [7]. Pea grown in pots with infected soil in 4 replications. Control was sterilized soil. Statistical analysis of experimental data was performed by the method of Dospehov B.A. [3].

Research results. In terms of the unit NUBiP Ukraine "Agronomic Research Station” of Kyiv region on pea crops detected essential defeat of plant by root rot. During the 2012 - 2013 growing seasons the spread of disease, depending on the variety ranged from 17,3 to $100 \%$, and its development was within $4,4-$ $67,8 \%$.

In problem research laboratory "Mycology and Phytopathology" of NUBiP Ukraine based on the results of phythopathological analysis of infected plants the highest frequency of isolation were 7 species of the genus Fusarium: F. moniliforme Sheld., F. solani (Mart.) App. et Wr., F. oxysporum (Schlecht) Snyd. et Hans., F. avenaceum (Fr.) Sacc, F. javanicum Koord, F. semitectum Berk. et Rav, F. sambusinum Fuck.

Often from affected tissues of root isolated to several different types of Fusarium simultaneously, which indicates the presence of complex pea root rot infection.

In artificially infected soil indicators of germination vigor, continued growth and development of Pea of variety is Skinado shown in figure 1. 


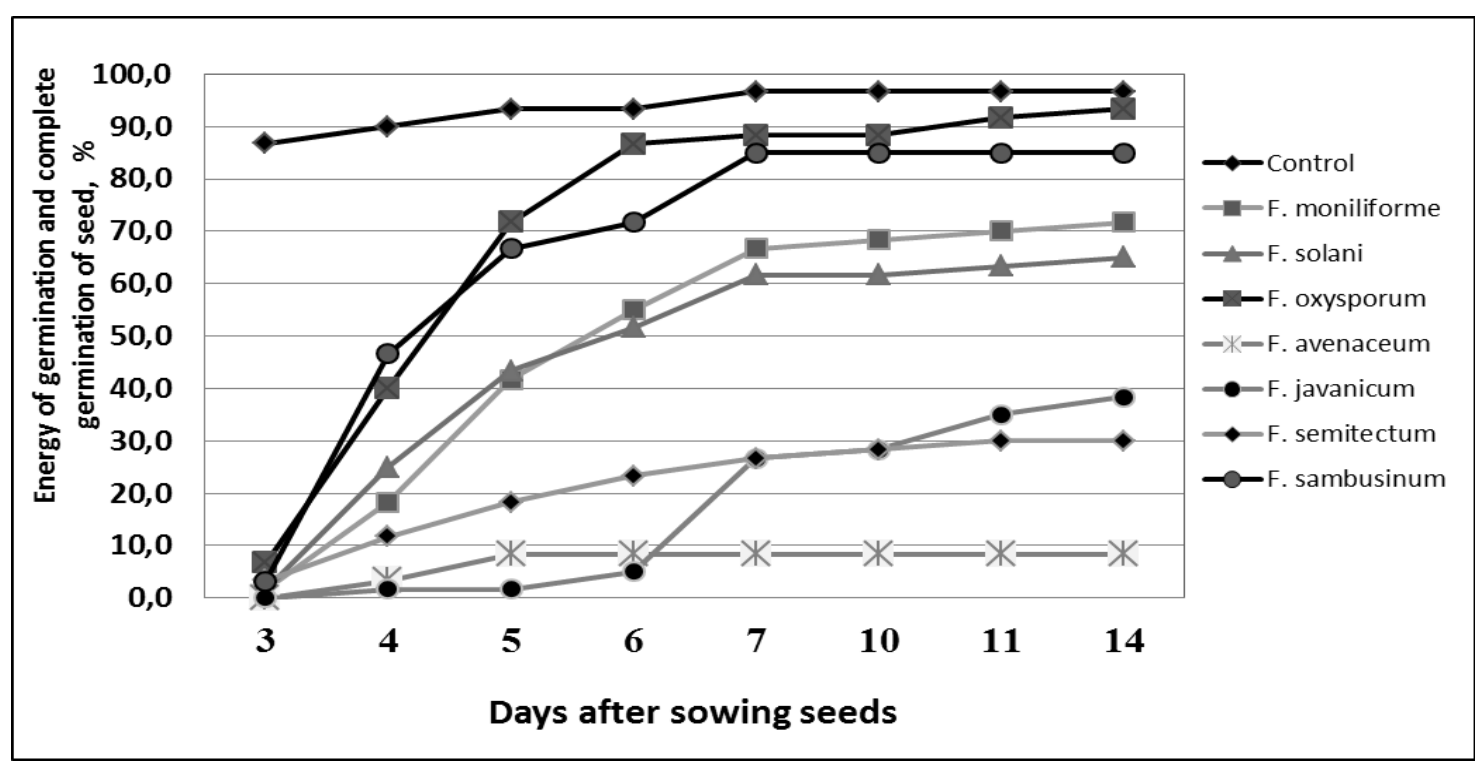

Fig. 1. Energy of germination and complete germination of vegetable peas seed in infected soil conditions (variety Scinado, problem research laboratory "Mycology and Phytopathology” of NUBiP Ukraine)

Energy of germination of peas (3 days after sowing) in infected background ranged from 1,7 (F. solani, F. moniliforme) to $6,7 \%$ (F. oxysporum), which is 85,0 and 80,0 less than in controls $(86,7 \%)$.

In other variants (F. javanicum and F. avenaceum) of the same period, seedlings were not found, indicating that the increased appearance of pathogenic properties of these fungi. Over 5-6 days above figures have increased significantly, except for options with $F$. avenaceum (8,3\%) and $F$. javanicum (5,0\%). In artificially infected with the fungus $F$. oxysporum background the part of seedlings increased to $86,7 \%, F$. sambusinum - 71,7\%, F. moniliforme $-55,0 \%$, F. solani $51,7 \%$ and $F$. semitectum - to $23,3 \%$.

7 days after planting under the influence of $F$. javanicum infection the number of plantlets was reduced to $70,0 \%, F$. avenaceum - on 88,4, F. semitectum - 70,0, F. solani - 35,0, F. moniliforme -30,0, F. sambusinum - 11,7 and F. oxysporum $-8,4 \%$ relative to the control (96,7\%) (fig. 2 ). 


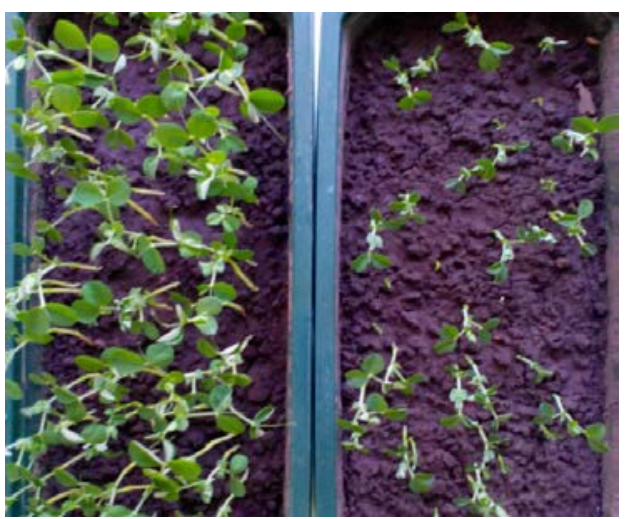

a

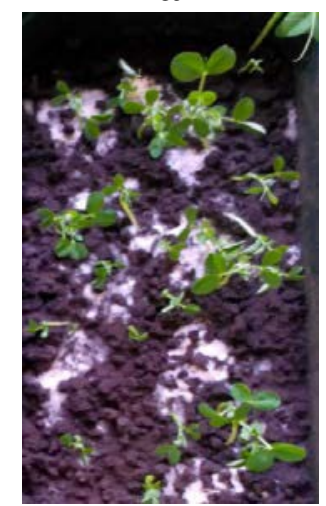

e

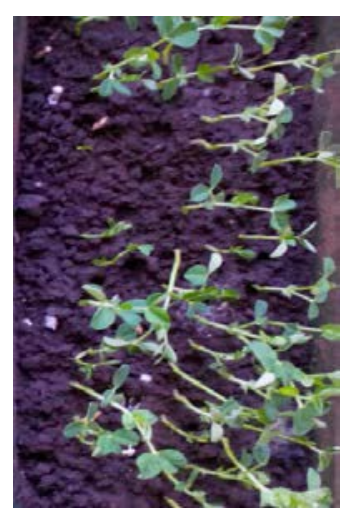

C

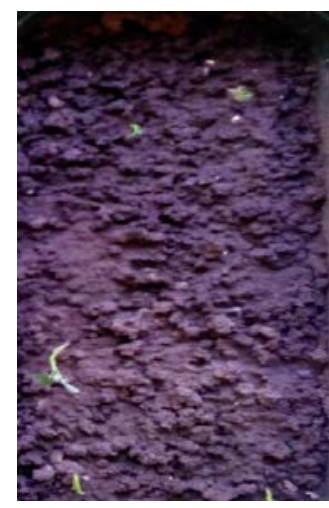

j

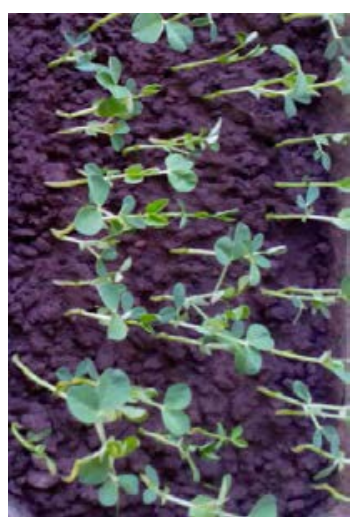

d

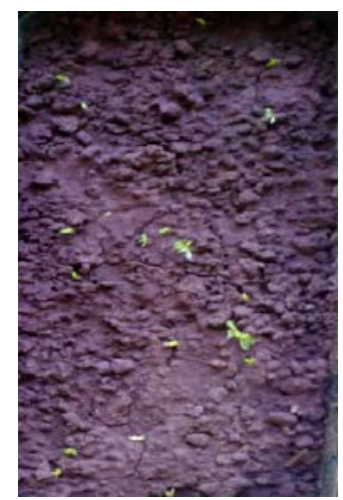

i

Fig. 2. Influence of infection by Fusarium species on germination pea: a контроль (без внесення грибів); b - F. moniliforme; c $-F$. охуsporum; d $-F$. sambusinum; e - F. solani; f - F. semitectum; j - F. avenaceum; i - F. javanicum (variety Scinado, problem research laboratory "Mycology and Phytopathology” of NUBiP Ukraine)

A similar pattern was found through 10-11 days after sowing the seeds, except variant of entering the soil fungus $F$. avenaceum, wherein the amount of seedling unchanged (8,3\%).

Two weeks after sowing the seeds in infected soil the largest number of plantlets we observed in variants with entering the soil $F$. oxysporum $(93,3 \%), F$. sambusinum (85,0\%), F. moniliforme (71,7 \%) and F. solani (65,0 \%), which respectively 3,4, 11,7, 25,0, 31,7 \% were less than in controls (96,7 \%). Among the studied species of Fusarium the greatest decrease pea seed germination caused by $F$. avenaceum, F. semitectum and F. javanicum. In these variants the number of seedlings amounted to 8,$3 ; 30,0$ and $38,3 \%$, which is 11,$6 ; 3,2$ and 2,5 times less than in control $(96,7 \%)$. 
The results of determining pathogenicity to pea root by above fungi are shown in figure 3.

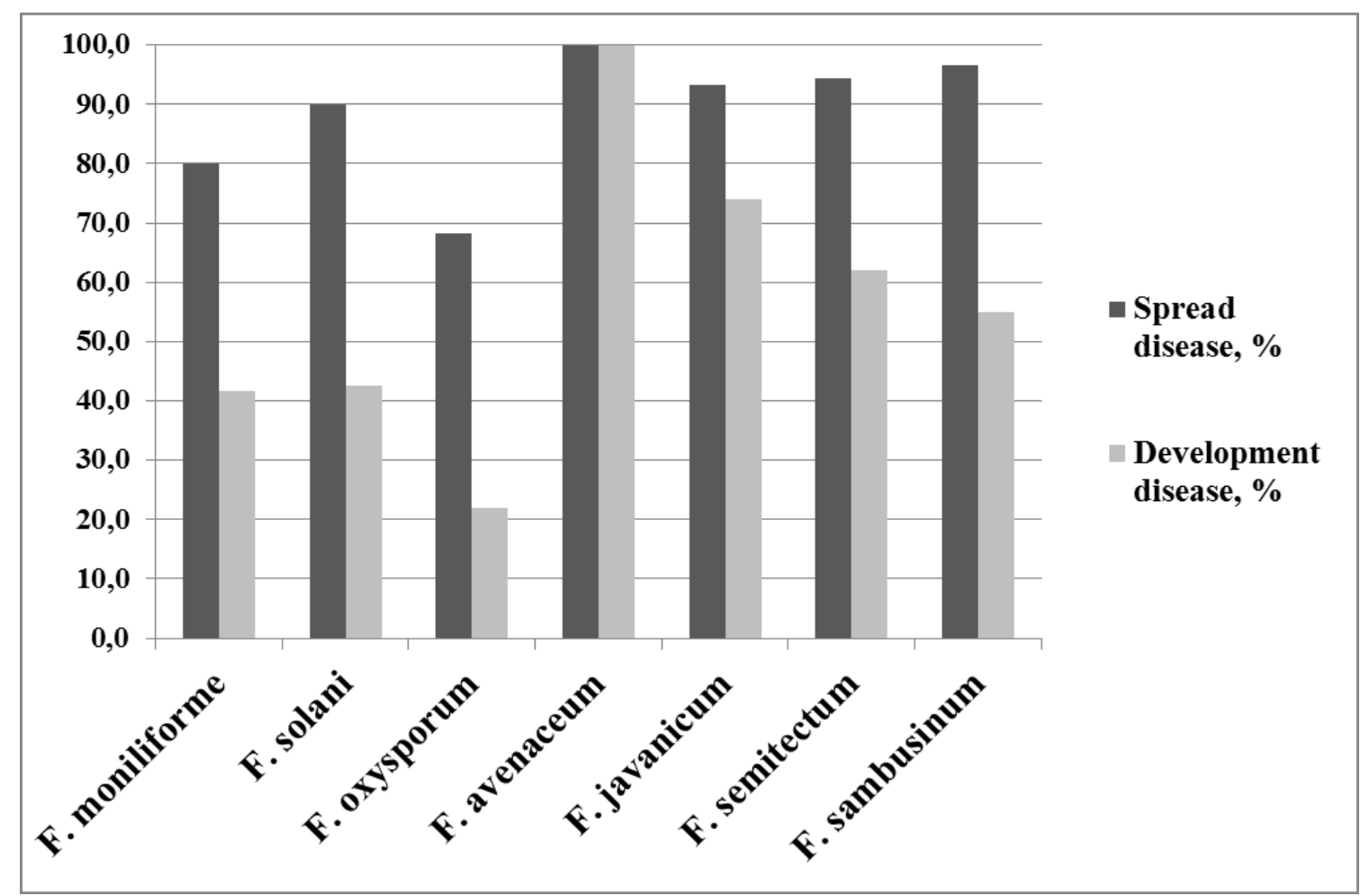

Fig. 3. Spread and development of Fusarium root rot of pea in artificially infected soil (variety Scinado, problem research laboratory "Mycology and Phytopathology" of NUBiP Ukraine)

In variants with soil infection of Fusarium species the largest number of infected plants were found in the application of $F$. avenaceum $(100 \%)$ and the lowest $-F$. oxysporum (68,2\%). In this case development of disease was 100 and $21,9 \%$ (fig. 4).

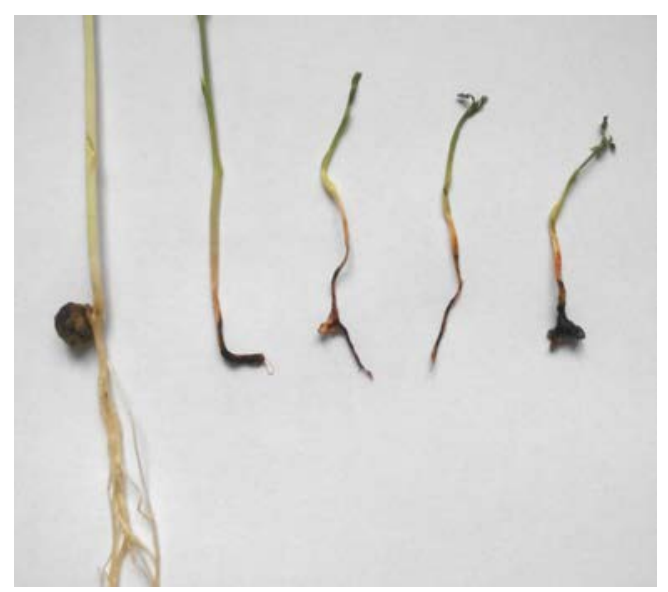

$\mathbf{a}$

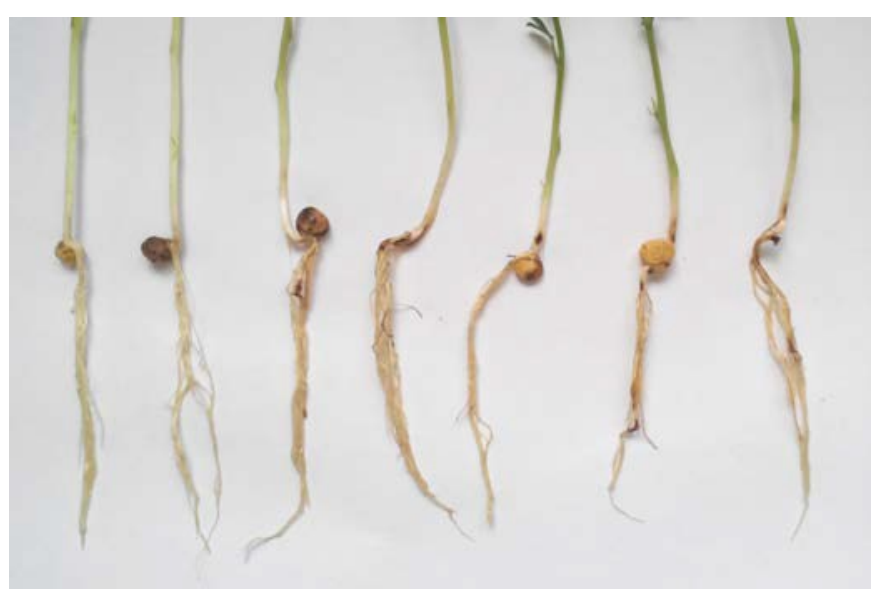

b

Fig. 4. Pea plants infected with F. avenaceum (a) i F. oxysporum (b) 
The spread of root rot if other modes of Fusarium ranged from 80,0 ( $F$. moniliforme) to $96,7 \%$ (F. sambusinum), and the development of disease ranged from 41,7 (F. moniliforme) - 74,1 (F. javanicum)\%.

The results of determination of influence of studied fungi on the growth and development of pea plants are shown in table 1. Height above-ground parts of the plant ranged from 3,7 (F. javanicum) to 16,5 (F. oxysporum) $\mathrm{cm}$., which is 81,9 and $19,1 \%$, respectively, lower than in controls $(20,4 \mathrm{~cm})$. In this case data between the average height of the stem in all versions and controls is a significant difference $\left(\mathrm{d}>H I P_{05}\right)$.

A similar pattern was observed on the length underground parts of plants. Among the species of Fusarium the least harm in relation to the development of the pea root system showed $F$. oxysporum $(9,3 \mathrm{~cm})$. In other variants, the root length ranged from 0,7 ( $F$. avenaceum) to $6,2 \mathrm{~cm}$ ( $F$. sambusinum), which is 93,2 and $39,8 \%$, respectively, lower than in control $(10,3 \mathrm{~cm})$.

In all variants with the introduction of root rot pathogens in the soil was observed suppression of mass aboveground plant parts. This is evidenced by the presence of significant differences between their means of indicators of various pathogens in the soil and control $\left(\mathrm{d}>H I P_{05}\right)$. The mass of above-ground parts of plants was in the range of 0,23 (F. semitectum) and 0,45 (F. oxysporum) g. The lowest rates were found in variants of $F$. avenaceum $(0,06 \mathrm{~g})$ and $F$. javanicum $(0,11 \mathrm{~g})$, which is 9,7 and 5,3 times was less than in control (0,58 g).

1. Effect of Fusarium root rot pathogens on growth and development pea in artificially infected background (variety Scinado, problem research laboratory “Mycology and Phytopathology” of NUBiP Ukraine)

\begin{tabular}{|c|c|c|c|c|c|c|}
\hline \multirow{2}{*}{$\begin{array}{l}\text { Adding to the } \\
\text { soil Fusarium } \\
\text { species }\end{array}$} & \multirow{2}{*}{$\begin{array}{l}\text { Plant } \\
\text { height, } \\
\text { cm }\end{array}$} & \multirow{2}{*}{$\begin{array}{l}\text { The } \\
\text { length } \\
\text { of the } \\
\text { main } \\
\text { root } \\
\text { plants } \\
\text { cm }\end{array}$} & \multicolumn{3}{|c|}{ Weight, g } & \multirow{2}{*}{$\begin{array}{c}\text { Number } \\
\text { of leaves } \\
\text { per plant, } \\
\text { units }\end{array}$} \\
\hline & & & $\begin{array}{l}\text { philosphera } \\
\text { plant, g }\end{array}$ & $\begin{array}{l}\text { underground } \\
\text { parts of the } \\
\text { plant, g }\end{array}$ & $\begin{array}{l}\text { the } \\
\text { whole } \\
\text { plant, } \\
\text { g }\end{array}$ & \\
\hline $\begin{array}{c}\text { Without } \\
\text { introduction }\end{array}$ & 20,4 & 10,3 & 0,58 & 0,22 & 0,80 & 17,0 \\
\hline
\end{tabular}




\begin{tabular}{|c|c|c|c|c|c|c|}
\hline fungi & & & & & & \\
\hline $\begin{array}{c}F . \\
\text { moniliforme }\end{array}$ & 12,0 & 5,1 & 0,27 & 0,06 & 0,33 & 11,0 \\
\hline F. solani & 10,9 & 4,0 & 0,26 & 0,07 & 0,33 & 11,1 \\
\hline F. oxysporum & 16,5 & 9,3 & 0,45 & 0,17 & 0,62 & 14,6 \\
\hline $\begin{array}{c}F . \\
\text { avenaceum }\end{array}$ & 5,4 & 0,7 & 0,06 & 0,01 & 0,07 & 2,2 \\
\hline F. javanicum & 3,7 & 4,2 & 0,11 & 0,07 & 0,18 & 2,2 \\
\hline $\begin{array}{c}F . \\
\text { semitectum }\end{array}$ & 10,8 & 4,7 & 0,23 & 0,05 & 0,28 & 9,5 \\
\hline $\begin{array}{c}F . \\
\text { sambusinum }\end{array}$ & 15,4 & 6,2 & 0,43 & 0,07 & 0,50 & 13,3 \\
\hline HIP 05 & 3,3 & 2,0 & 0,11 & 0,04 & 0,15 & 4,3 \\
\hline
\end{tabular}

Under the influence of Fusarium root rot pathogens, except $F$. oxysporum, the root system of plants developed very poorly. Its weight varied from 0,01 ( $F$. avenaceum) to $0.07 \mathrm{~g}$ (F. solani, F. sambusinum and F. javanicum), which is 95,5 and $68,2 \%$ was lower than the control $(0,22 \mathrm{~g})$. The average values of these parameters were compared with control significant difference $\left(\mathrm{d}>H I P_{05}\right)$, except F. oxysporum $(0,17 \mathrm{~g})$.

In variants with $F$. moniliforme, $F$. solani, $F$. semitectum, $F$. avenaceum and F. javanicum was significantly different from the control number of leaves per plant. It accordingly amounted to 11,0 pc; 11,1; 9,5; 2,2; 2,2.

In other variants, this figure corresponded to 14,6 (F. oxysporum) and 13,3 (F. sambusinum).

Conclusions. Based on the obtained results (indicators of seed germination and emergence, spread of root rot, plant growth) we detected pathogenic features of 7 studied fungi of the genus Fusarium: F. moniliforme Sheld., F. solani (Mart.) App. et Wr., F. oxysporum (Schlecht) Snyd. et Hans., F. avenaceum (Fr.) Sacc, F. javanicum Koord, F. semitectum Berk. et Rav, F. sambusinum Fuck. In the laboratory on artificial infectious background against the pea the most harmful species showed $F$. avenaceum and $F$. javanicum, and the least $-F$. oxysporum. 
Under their influence seed grown very slowly, in the most cases its rotted and therefore did not give seedlings. According to the results of the biometric analysis, the main and lateral roots infected seedlings formed poorly, leaves on the stems often not developed.

\section{Bibliograpy}

1. Билай В.И. Фузарии / В.И. Билай. - К.: «Наукова думка», 1977. - 442 с.

2. Борзенкова Г.А. Система рационального применения протравителей и оптимизация их современного использования с биопрепаратами и ФАВ в защите гороха от болезней в условиях Юга нечернозёмной зоны России / Г.А. Борзенкова // Научно-производительный журнал «Зернобобовые и крупяные культуры. - 2012. - № 1. - С. 90 - 98.

3. Доспехов Б. А. Методика полевого опыта (с основами статистической обработки результатов исследований) / Б. А. Доспехов. - М.: Агропромиздат, 1985. - 351 с.

4. Кирик М. М. Особливості розвитку кореневих гнилей сочевиці / М. М. Кирик, Ю. М. Таранухо, М. Й. Піковський // Карантин і захист рослин - № 5. - 2013. - C. 11-13.

5. Методические указания по диагностике фитофторозов, корневых гнилей и увядания бобовых культур / В. В. Котова, Д. Ш. Чакаев, Н.А. Цветкова. - Л.: ВИЗР, 1990. - 27 с.

6. Методические указания по диагностике фузариозов зернобобовых культур / М. Ю. Степанова, А. А. Бенкен., М. К. Хохрякова. - Л.: ВИЗР, 1968. - 22 c.

7. Методологія оцінювання стійкості сортів пшениці проти шкідників i збудників хвороб / С. О. Трибель, М. В. Ретьман, О. О. Стригун [та ін.]., за ред. С. О. Трибель. - К.: Колобіг, 2010. - 392 с.

8. Abawi G.S. Root rots of beans in Latin America and Africa: diagnosis, research methodologies and management strategies / G.S Abawi, M.A. 
Corrales - Columbia: Centro International de Agricultura Tropical, 1990. P 114.

9. Abdul Wahid O.A. Improving control Fusarium wilt of leguminous plants by combined application of biological agents / O.A. Abdul Wahid // Phytopathologia Mediterranea. - 2006. - Vol. 45, No. 3. - P. 231-237.

10.Mazur S. Disease symptoms on chickpea (Cicer arietinum L.) and their causal agents / S. Mazur, J. Nawrocki // Folia horticulturae. - 2004. - № 16 (1). - P. 47-53.

11. Singh G. Fungal diseases of pulses / G. Singh, Y.R. Sharma // Diseases of field crops. Indus Publishing, New Delhi, India. - 2002. - P. 155-192. 